Article

\title{
Replicating Smart Cities: The City-to-City Learning Programme in the Replicate EC-H2020-SCC Project
}

\author{
Igor Calzada ${ }^{1,2} \mathbb{D}$ \\ 1 Urban Transformations ESRC \& Future of Cities Programmes, COMPAS, University of Oxford, \\ 58 Banbury Road, Oxford OX2 6QS, UK; igor.calzada@compas.ox.ac.uk or igor.calzada@ec.europa.eu; \\ Tel.: +44-7887-661-925 \\ 2 Digital Economy Unit \& Centre for Advanced Studies (CAS), DG Joint Research Centre (JRC), \\ European Commission, Via Fermi 2749, 21027 Ispra, Italy
}

Received: 31 July 2020; Accepted: 3 September 2020; Published: 8 September 2020

\begin{abstract}
This article addresses the problem of replication among smart cities in the European Commission's Horizon 2020: Smart Cities and Communities (EC-H2020-SCC) framework programme. This article initially sets the general policy context by conducting a benchmarking about the explicit replication strategies followed by each of the 17 ongoing EC-H2020-SCC lighthouse projects. This article aims to shed light on the following research question: Why might replication not be happening among smart cities as a unidirectional, hierarchical, mechanistic, solutionist, and technocratic process? Particularly, in asking so, it focuses on the EC-H2020-SCC Replicate project by examining in depth the fieldwork action research process implemented during 2019 through a knowledge exchange webinar series with participant stakeholders from six European cities-three lighthouse cities (St. Sebastian, Florence, and Bristol) and three follower-fellow cities (Essen, Lausanne, and Nilüfer). This process resulted in a City-to-City Learning Programme that reformulated the issue of replication by experimenting an alternative and an enhanced policy approach. Thus, stemming from the evidence-based policy outcomes of the City-to-City Learning Programme, this article reveals that a replication policy approach from the social innovation lenses might be enabled as a multidirectional, radial, dynamic, iterative, and democratic learning process, overcoming the given unidirectional, hierarchical, mechanistic, solutionist, and technocratic approach.
\end{abstract}

Keywords: smart cities; social innovation; replication; city-to-city learning; policy; Europe; action research; GDPR; COVID-19; solutionism

\section{Introduction}

In recent years, the concept of smart cities has gained momentum among policymakers in Europe [1-7]. Moreover, smart cities have certainly reached the post-General Data Protection Regulation (GDPR) algorithmic era [8-10], where a truly smart city in Europe could be established, in which citizens can move in relative anonymity and be identified only when needed and under conditions that allow for significant control over what can be done with their own data [11,12]. Actually, the GDPR provides a regulatory framework to protect citizens' personal data subject to being accurately considered, making replication a complex procedure beyond the mechanistic and solutionist mainstream approach. Consequently, replication in smart cities should be experimented and re-implemented, paying substantial attention to unique data-driven post-COVID-19 European contexts, currently especially sensitive to contact apps and geolocalised information about citizens to avoid axiomatic failures whereby all urban ills are resolved through mechanistic solutions.

Hence, against the backdrop of this self-demanding scenario, city representatives in Europe are not solely in charge of coordinating funded lighthouse projects under the European Commission's 
Horizon 2020: Smart Cities and Communities (EC-H2020-SCC) framework programme [13-18]. This group must also engage in joint and continuous conversations with diverse and numerous groups of city-regional stakeholders, as well as consider a generation of smart technologies (including the increasingly autonomous machine intelligence that can gather and analyse granular and real-time "big data") if it is to effectively tackle the most pressing economic, technologic, ethical, and social issues that face European cities [15,19-21]. The smart cities that prosper in the future will likely be those that are best equipped at learning from other cities and high-tech conurbations-and directly from their stakeholders-for replicating, experimenting, adapting, and scaling up initiatives by adopting a complex and socially innovative constellation of post-GDPR smart technologies predicated upon Artificial Intelligence (AI) and reflexive autonomous Machine Learning, digital innovation and the Internet of Things (enhanced by $5 \mathrm{G}$ and new sensor technologies), and quantum leaps in data infrastructure and capacities [22-24]. Additionally, city representatives should be equally prepared to identify the risks and vulnerabilities associated with the techno-politics of data and the democratic misalignment that the gig economy generates through disruptions and power imbalances among stakeholders [12,25-30], particularly relevant from the GDPR perspective to protect workers and citizens from the negative side-effects of the COVID-19 aftermath in European cities. To some extent, city representatives should approach replication as a highly contextual process by which the consideration of the place, the localisation in itself, and, more importantly, the mobility of citizens seem to matter now more than ever before.

In the EC-H2020-SCC policy framework [17] (p. 8), replication is defined as "the possibility of transporting or copying results from a pilot case to other geographical areas, albeit potentially different boundary conditions," thus slightly recommending that "if a pilot was proven to work in one community or region, it could be exported to other communities or regions (indigenously or abroad), but taking into account that the boundary conditions could be quite different from those in piloted community or region."

However, far from being prepared for such a complex techno-political scenario, the policy framework design by the EC-H2020-SCC explicitly encourages cities and their representatives to apply pure replication without deeply considering the examination of further contextual elements characterising the uniqueness, singularity, adaptability, and scalability of the projected urban interventions [14-17]. Actually, in these replicated interventions, ecosystems of stakeholders and their related power interdependencies ultimately seem to define the adoption of one or another technology more than their mere rational and mechanistic cost-value analysis [31-35]. As such, the GDPR has introduced clear compliances and measures for particular stakeholders operating in specific contexts, which is already affecting the adoption of smart actions further in one or another direction.

In contrast, a report also published by the EC [36] (p. 1) strikingly confirms the hypothesis in line with the research question that this article attempts to shed light on: "replication may not be happening" among smart cities of the EC-H2020-SCC framework programme, as the policy designers extrapolated. As such, the notable conclusion of this report is the point of departure of this article when it refers to replication as "a quest for the Holy Grail: everyone is searching, but no one seems to be able to find it" [36] (p. 6). The report clearly states that the replication of smart urban energy, mobility, and Information Communication Technologies (ICT) solutions for a clean energy future is challenging. The report reveals that $70 \%$ of the currently existing smart city pilot interventions are undermined due to very "specific solutions that are difficult to adapt to local contexts" [36] (p. 8). To some extent, this report resonates with the rebuttal statement formulated by the urban scholar, Ayona Datta, and with this article, thereby making sense of the replication panacea deadlock in the policymaking of smart cities, as formulated so far by the EC: "The "urban" is not "science". It cannot be measured, replicated, and forecast like other sciences. The urban is an imaginary, a relationship between multiple spaces and scales from the personal to the global, a site of politics and governance. The urban is much more than "science"" [37] (p. 1). Thus, stemming from the abovementioned hypothesis [36], 
this article sheds light on the following research question: Why might replication not be happening among smart cities as a unidirectional, hierarchical, mechanistic, solutionist, and technocratic process?

To illuminate on this discussion by making it accessible to the reader without much knowledge of the EC-H2020-SCC policy framework, this article considers the main findings of the fieldwork action research [38,39] and the project documents [13-18], undertaken in the specific EU-H2020-SCC Replicate project from February 2016 to December 2019. This action was operationally embodied in the City-to-City Learning Programme during the entirety of 2019, with the direct involvement of the six Replicate cities, without making any hierarchical distinction among the three lighthouse cities, (San Sebastian in Spain, Florence in Italy, and Bristol in the United Kingdom), as well as the three follower or fellow cities (Essen in Germany, Lausanne in Switzerland, and Nilüfer in Turkey), as established explicitly by the programme. The term used to refer to the latter has been changed during the implementation of the EC-H2020-SCC framework programme from follower cities to fellow cities, which may slightly show the potential misalignment and the subsequent gradual fix in the understanding of the replication function among different cities, regardless of their hierarchical position. Furthermore, from the start, the replication nature appeared to be even more challenging in the EC-H2020-SCC Replicate project, as follower cities were relegated to a passive role in processes for being unidirectional, hierarchical, mechanistic, solutionist [40], and technocratic. Local stakeholders in each fellow city were depicted only as developers of solutions already prepared and packed in the lighthouse cities. This replication-driven policy design took for granted the assumption that the three lighthouse cities could be the only ones spelling out urban solutions, without considering whether, first, the urban implementations in the lighthouse cities were appropriate for the fellow cities, and, second, the fellow cities already had ongoing replicable models worth considering. Instead, this article offers an experimental alternative from the social innovation perspective [22,41-44] by offering an enhanced policy approach. That is, interaction and learning among cities and their related stakeholders would be multidirectional, radial, dynamic, iterative, and democratic. Consequently, the objective of this article is to show the experimental alternative replication pathway as it has been demonstrated through a fieldwork action research process within the EC-H2020-SCC Replicate project among six European cities towards a less unidirectional, hierarchical, mechanistic, solutionist, and technocratic approach for replication between smart cities. This fieldwork action research resulted in the City-to-City-Learning Programme. Insofar as the research questions attempts to shed light on why replication might not be happening in smart cities as anticipated by policymakers [36], the objective of the article is essentially to show an alternative pathway and an enhanced policy approach that the EC-H2020-SCC Replicate project experimented among the six participant cities, and more importantly, their stakeholders. The fourth section in this article, Results, illustrates how the EC-H2020-SCC Replicate project proceeded implementing a fieldwork action research by showing a potential alternative to face the research question through the objective of this article: to introduce the City-to-City-Learning Programme by experimenting five transitions from the social innovation perspective.

Hence, this article contributes to the literature on the replication problem among smart cities by revealing the research findings and results from the Replicate EC-H2020-SCC project and challenging the given institutional, technocratic (as described by Morozov) policy guidelines applied in lighthouse cities to follower-fellow cities. It, instead, examines the alternative, more diverse, and democratic process of interaction and learning in the six Replicate cities. The fieldwork took the form of a webinar series, City-to-City Learning Programme [45], in two phases. First, it employed the active direct engagement of the wide range of EU-Replicate project's stakeholders (150 registered participants and almost 300 offline views). Second, it employed broad dissemination among the network of stakeholders of the 17 lighthouse projects by reaching the entire H2020-SCC targeted audience [46]. The resulting programme was operationalised through the leading role of the six-city Replicate representatives who acted as intermediaries and bricoleurs of the replication-learning process [47-49]. In the proposed programme, the concept replication was channelled through a learning loop characterised by singularity, adaptability, and scalability. It is worth highlighting this webinar series occurred before the COVID-19 
outbreak, when face-to-face interaction was the norm, unlike the online and remote current one. Therefore, this article gathered the information through fieldwork action research retrospectively, and in a very different context for all stakeholders, the project, and overall general context.

This article proceeds as follows. Section 2 examines the policy context until 2019, encompassing 17 lighthouse projects (46 lighthouse cities and 71 fellow cities) with their related replication strategies, city composition, networks, and stakeholders' involvement [50]. Section 3 reviews the literature from the social innovation perspective to shed light on the research question [41-44,51,52]. Section 4 objectively describes how the City-to-City Learning Programme was established and implemented among the six Replicate cities as an alternative replication pathway by experimenting an enhanced policy approach through fieldwork action research [38,39]. Section 5 presents the potential content for the replication plans that fellow cities are currently co-producing as a direct result stemming from the City-to-City Learning Programme. The article, consequently, further examining the fieldwork action research results experimented jointly by the six cities in the EC-H2020-SCC Replicate project, concludes by suggesting five potential transitions to enhance replication among smart cities' stakeholders and outlines directions for future research on social innovation.

\section{Policy Context: Benchmarking EC-H2020-SCC Lighthouse Projects' Replication Strategies}

This section analyses policy documents of the EC-H2020-SCC framework programme and [13-18], in particular, conducts a generic benchmarking about the explicit replication strategies mentioned through the websites and materials provided by each of the 17 ongoing lighthouse projects [45,53-68]. However, it is worth clarifying that this section comparatively identifies general traces and policy evidence on the EC-H2020-SCC policy context by focusing somewhat on the specific strategic formulation about replication in the ongoing 17 lighthouse projects. It is, therefore, outside the scope of this article to offer an exhaustive and in-depth analysis of each project's replication strategy and process.

However, the article shows the specific examples stemming from the six cities of the Replicate project that may inspire, in the future, other replication implementations in smart cities elsewhere. The objective of the article, thus, is to offer an alternative to pure replication through reformulating the issue of replication by experimenting an alternative and an enhanced policy approach.

It goes without saying that replication has played an important role in the past in helping implementation of IT interventions. Nonetheless, the article attempts to show an evolutionary trend occurring among the EC-H2020-SCC lighthouse projects by which the effectiveness of pure replicability encounters shortcomings that go beyond pure IT interventions. At present, GDPR has allowed a European strategy on data and, more recently, a new European data governance strategy that since February 2020 is being translated into facilitating the use and protection of citizens' personal data. This fact, amidst the post-COVID-19 uncertain timeframe may entail a further rigorous contextual and place-based assessment to implement replication. In the post-COVID-19 era, it is becoming rather clear that particularities matter, even more so when data privacy and ownership are at stake.

This article, thus, presents data and information stemming from the fieldwork action research process among the stakeholders of six European cities entirely involved in a learning cycle from January to December 2019. Amidst the current post-COVID-19 circumstances and in the aftermath of the GDPR, the process, retrospectively speaking, implemented through this time shows even further relevance to avoid a pure mechanistic approach.

Based on the analysis shown in Table 1, there are three takeaways for benchmarking the process of replication among smart cities, which this article highlights [69]. 
Table 1. Benchmarking EC-SCC-H2020 Lighthouse Projects. Replication Strategy [13]. Source: www.replicate-project.eu/city2citylearning.

\begin{tabular}{|c|c|c|c|c|}
\hline \multirow{2}{*}{$\begin{array}{l}17 \text { Lighthouse } \\
\text { Projects } \\
\text { (up to 2019) }\end{array}$} & \multicolumn{2}{|c|}{ City-Network-Composition } & \multirow{2}{*}{$\begin{array}{l}\text { Round/Period/Budget/ } \\
\text { Website }\end{array}$} & \multirow{2}{*}{$\begin{array}{c}\text { Replication Strategy: } \\
\text { (LC = Lighthouse Cities; } \\
\text { FC = Follower-Fellow Cities) }\end{array}$} \\
\hline & Lighthouse Cities (46) & Follower-Fellow Cities (71) & & \\
\hline 1. Growsmarter & $\begin{array}{l}\text { Stockholm, SE } \\
\text { Barcelona, ES } \\
\text { Koln, DE }\end{array}$ & $\begin{array}{l}\text { Cork, IE } \\
\text { Graz, AT } \\
\text { Porto, PT } \\
\text { Suceava, RO } \\
\text { Valetta, MT }\end{array}$ & $\begin{array}{l}\text { SCC1-2014 } \\
\text { 2015-2019 } \\
\text { 34M€ } \\
\text { https://grow-smarter.eu/home/ }\end{array}$ & $\begin{array}{l}\text { Based on 'twelve groups of smart solutions entirely developed by } \\
\text { the LC to be, thereafter, tested and adopted by the FC' [62] (p. 3). }\end{array}$ \\
\hline 2. Remourban & $\begin{array}{l}\text { Nottingham, UK } \\
\text { Tebebasi, TR } \\
\text { Valladolid, ES }\end{array}$ & $\begin{array}{l}\text { Miskolc, HU } \\
\text { Seraing, BE }\end{array}$ & $\begin{array}{l}\text { SCC1-2014 } \\
2015-2019 \\
23 \mathrm{M} € \\
\text { http://www.remourban.eu/ }\end{array}$ & $\begin{array}{l}\text { Based on LC supply to FC demands' being entirely separated } \\
\text { procedures [67] (p. 4). }\end{array}$ \\
\hline 3. Triangulum & $\begin{array}{l}\text { Stavanger, NO } \\
\text { Eindhoven, NL } \\
\text { Manchester, UK }\end{array}$ & $\begin{array}{l}\text { Tianjin, CHN } \\
\text { Leipzig, DE } \\
\text { Prague, CZ } \\
\text { Sabadell, ES }\end{array}$ & $\begin{array}{l}\text { SCC1-2014 } \\
2015-2019 \\
29 \mathrm{M} € \\
\text { http: } \\
\text { //www.triangulum-project.eu/ }\end{array}$ & $\begin{array}{l}\text { Based on 'a replication tool shown as a smart city } \\
\text { decision-making tool, which stores the smart solutions achieved } \\
\text { by the LC' [61] (p. 1). }\end{array}$ \\
\hline 4. Replicate & $\begin{array}{l}\text { San Sebastian-Donostia, ES } \\
\text { Bristol, UK } \\
\text { Florence, IT }\end{array}$ & $\begin{array}{l}\text { Essen, DE } \\
\text { Lausanne, CH } \\
\text { Nilüfer, TR }\end{array}$ & $\begin{array}{l}\text { SCC1-2015 } \\
2016-2021 \\
29 \mathrm{M} € \\
\text { www.replicate-project.eu }\end{array}$ & $\begin{array}{l}\text { Based on the City-to-City Learning Programme adopting a } \\
\text { multidirectional approach jointly among the LC and FC' from the } \\
\text { early beginning of } 2016 \text { [45]. }\end{array}$ \\
\hline 5. Sharing Cities & $\begin{array}{l}\text { London, UK } \\
\text { Lisbon, PT } \\
\text { Milan, IT }\end{array}$ & $\begin{array}{l}\text { Bordeaux, FR } \\
\text { Burgas, BG } \\
\text { Warsaw, PL }\end{array}$ & $\begin{array}{l}\text { SCC1-2015 } \\
2016-2020 \\
28 \mathrm{M} € \\
\text { http://www.sharingcities.eu/ }\end{array}$ & $\begin{array}{l}\text { Based on 'the ambition being not less than making each follower } \\
\text { city to be treated and make them act as a fellow city' }[68] \text { (p. 6). }\end{array}$ \\
\hline 6. SmartenCity & $\begin{array}{l}\text { Vitoria-Gasteiz, ES } \\
\text { Sonderborg, DK } \\
\text { Tartu, EE }\end{array}$ & $\begin{array}{l}\text { Asenovgrad, GB } \\
\text { Lecce, IT }\end{array}$ & $\begin{array}{l}\text { SCC1-2015 } \\
2016-2021 \\
32 \mathrm{M} € \\
\text { https://smartencity.eu/ }\end{array}$ & $\begin{array}{l}\text { Based on 'capacity building workshops and thematic webinars } \\
\text { from the LC to FC' [66] (p. 51). }\end{array}$ \\
\hline 7. Smarter Together & $\begin{array}{l}\text { Lyon, FR } \\
\text { Munich, DE } \\
\text { Vienna, AT }\end{array}$ & $\begin{array}{l}\text { Santiago de Compostela, ES } \\
\text { Sofia, BG } \\
\text { Venice, IT } \\
\text { Yokohama, JP } \\
\text { Kiev, UA }\end{array}$ & $\begin{array}{l}\text { SCC1-2015 } \\
2016-2021 \\
29 \mathrm{M} € \\
\text { https: } \\
\text { //www.smarter-together.eu/ }\end{array}$ & $\begin{array}{l}\text { Based on 'enablers, key problems and challenges and solutions of } \\
\text { the LC to be reproduced in the FC by gradually engaging them in } \\
\text { the process' [63] (p. 7). }\end{array}$ \\
\hline
\end{tabular}


Table 1. Cont.

\begin{tabular}{|c|c|c|c|c|}
\hline \multirow{2}{*}{$\begin{array}{l}17 \text { Lighthouse } \\
\text { Projects } \\
\text { (up to 2019) }\end{array}$} & \multicolumn{2}{|c|}{ City-Network-Composition } & \multirow{2}{*}{$\begin{array}{l}\text { Round/Period/Budget/ } \\
\text { Website }\end{array}$} & \multirow{2}{*}{$\begin{array}{c}\text { Replication Strategy: } \\
\text { (LC = Lighthouse Cities; } \\
\text { FC = Follower-Fellow Cities) }\end{array}$} \\
\hline & Lighthouse Cities (46) & Follower-Fellow Cities (71) & & \\
\hline 8. My Smart Life & $\begin{array}{l}\text { Nantes, FR } \\
\text { Hamburg, DE } \\
\text { Helsinki, FI }\end{array}$ & $\begin{array}{l}\text { Bydgoszcz, PL } \\
\text { Palencia, ES } \\
\text { Rijeka, HR } \\
\text { Varna, BG }\end{array}$ & $\begin{array}{l}\text { SCC1-2016 } \\
2016-2021 \\
21 \mathrm{M} € \\
\text { https://www.mysmartlife.eu/ }\end{array}$ & $\begin{array}{l}\text { Based on 'stage 2, after LC interventions, where FC will be } \\
\text { involved, which are going to be learning during the project from } \\
\text { the LC, and will apply their replication plans' [65] (p. 8). }\end{array}$ \\
\hline 9. Ruggedised & $\begin{array}{l}\text { Rotterdam, NL } \\
\text { Glasgow, UK } \\
\text { Umea, SE }\end{array}$ & $\begin{array}{l}\text { Brno, CZ } \\
\text { Gdansk, PL } \\
\text { Parma, IT }\end{array}$ & $\begin{array}{l}\text { SCC1-2016 } \\
2017-2021 \\
19 \mathrm{M} € \\
\text { https://ruggedised.eu/ }\end{array}$ & $\begin{array}{l}\text { Based on ' } 32 \text { smart solutions in the LC and } 27 \text { follower solutions } \\
\text { in the FC being entirely autonomous procedures' [58] (p. 1). }\end{array}$ \\
\hline 10. IRIS & $\begin{array}{l}\text { Nice, FR } \\
\text { Gothenburg, SE } \\
\text { Utrecht, NL }\end{array}$ & $\begin{array}{l}\text { Alexandroupolis, GR } \\
\text { Focsani, RO } \\
\text { Santa Cruz de Tenerife, ES } \\
\text { Vaasa, FI }\end{array}$ & $\begin{array}{l}\text { SCC1-2016 } \\
2017-2022 \\
20 \mathrm{M} € \\
\text { https://irissmartcities.eu/ }\end{array}$ & $\begin{array}{l}\text { Based on 'processes for scaling the solutions both inside and } \\
\text { outside of the consortium' [64] (p. 38). }\end{array}$ \\
\hline 11. Matchup & $\begin{array}{l}\text { Valencia, ES } \\
\text { Antalya, TR } \\
\text { Dresden, DE }\end{array}$ & $\begin{array}{l}\text { Herzliya, IL } \\
\text { Kerava, FI } \\
\text { Ostend, BE } \\
\text { Skopje, MA }\end{array}$ & $\begin{array}{l}\text { SCC1-2016 } \\
2017-2022 \\
19 \mathrm{M} € \\
\text { https: } \\
\text { //www.matchup-project.eu/ }\end{array}$ & Based on 'active involvement organising events' [56] (p. 1). \\
\hline 12. Stardust & $\begin{array}{l}\text { Pamplona-Iruñea, ES } \\
\text { Tampere, FI } \\
\text { Trento, IT }\end{array}$ & $\begin{array}{l}\text { Derry, UK } \\
\text { Kozani, GR } \\
\text { Cluj-Napoca, RO } \\
\text { Litomerice, CZ }\end{array}$ & $\begin{array}{l}\text { SCC1-2016 } \\
2017-2022 \\
21 \mathrm{M} € \\
\text { http://stardustproject.eu/ }\end{array}$ & $\begin{array}{l}\text { Based on 'FC will take into consideration the actions carried in } \\
\text { the LC'. [60] }\end{array}$ \\
\hline 13. Making City & $\begin{array}{l}\text { Groningen, NL } \\
\text { Oulu, FI }\end{array}$ & $\begin{array}{l}\text { Vidin, BG } \\
\text { Bassano del Grappa, IT } \\
\text { Lublin, PL } \\
\text { Poprad, SK } \\
\text { León, ES } \\
\text { Kadikoy, TR } \\
\end{array}$ & $\begin{array}{l}\text { SCC1-2017 } \\
2018-2023 \\
20 \mathrm{M} € \\
\text { http://makingcity.eu/ }\end{array}$ & $\begin{array}{l}\text { Based on 'the concept of Positive Energy District (PED) that will } \\
\text { be tested and validated in two LC, and later will be replicated in } 6 \\
\text { FC' [55]. }\end{array}$ \\
\hline 14. City Exchange & $\begin{array}{l}\text { Limerick, IE } \\
\text { Trondheim, NO }\end{array}$ & $\begin{array}{l}\text { Smolyan, BG } \\
\text { Pisek, CZ } \\
\text { Voru, EE } \\
\text { Alba Iulia, RO } \\
\text { Sestao, ES }\end{array}$ & $\begin{array}{l}\text { SCC1-2018 } \\
2018-2023 \\
24 \mathrm{M} € \\
\text { https://cityxchange.eu/ }\end{array}$ & $\begin{array}{l}\text { Based on 'the demonstration projects [that] are developed in the } \\
\text { LC and will be replicated in five FC' [54]. }\end{array}$ \\
\hline
\end{tabular}


Table 1. Cont

\begin{tabular}{|c|c|c|c|c|}
\hline \multirow{2}{*}{$\begin{array}{l}17 \text { Lighthouse } \\
\text { Projects } \\
\text { (up to 2019) }\end{array}$} & \multicolumn{2}{|c|}{ City-Network-Composition } & \multirow{2}{*}{$\begin{array}{c}\text { Round/Period/Budget/ } \\
\text { Website }\end{array}$} & \multirow{2}{*}{$\begin{array}{c}\text { Replication Strategy: } \\
\text { (LC = Lighthouse Cities; } \\
\text { FC = Follower-Fellow Cities) }\end{array}$} \\
\hline & Lighthouse Cities (46) & Follower-Fellow Cities (71) & & \\
\hline 15. Atelier & $\begin{array}{l}\text { Bilbao, ES } \\
\text { Amsterdam, NL }\end{array}$ & $\begin{array}{l}\text { Copenhagen, DK } \\
\text { Budapest, HR } \\
\text { Riga, LV } \\
\text { Krakow, PL } \\
\text { Matosinhos, PT } \\
\text { Bratislava, SK }\end{array}$ & $\begin{array}{l}\text { SCC1-2018 } \\
2019-2024 \\
21 \mathrm{M} € \\
\text { http: } \\
\text { //www.smartcity-atelier.eu/ }\end{array}$ & No information provided on replication strategy yet [53]. \\
\hline 16. Pocityf & $\begin{array}{l}\text { Evora, PT } \\
\text { Alkmaar, NL }\end{array}$ & $\begin{array}{l}\text { Hvidovre, DK } \\
\text { Ioannina, GR } \\
\text { Ujpest, HU } \\
\text { Bari, IT } \\
\text { Celje, SI } \\
\text { Granada, ES }\end{array}$ & $\begin{array}{l}\text { SCC1-2018 } \\
2019-2024 \\
22 \mathrm{M} € \\
\text { https://pocityf.eu/ }\end{array}$ & No information provided on replication strategy yet [57]. \\
\hline 17. Sparcs & $\begin{array}{l}\text { Espoo, FI } \\
\text { Leipzig, DE }\end{array}$ & $\begin{array}{l}\text { Kladno, CZ } \\
\text { Kifissia, GR } \\
\text { Reykjavik, IS } \\
\text { Maia, PT } \\
\text { Lviv, UA }\end{array}$ & $\begin{array}{l}\text { SCC1-2018 } \\
2019-2024 \\
23 \mathrm{M} € \\
\text { https://www.sparcs.info/ }\end{array}$ & $\begin{array}{l}\text { Based on 'LC proving the urban energy transformation while FC } \\
\text { demonstrates the smooth transferability of this transformation } \\
\text { model' [59]. }\end{array}$ \\
\hline
\end{tabular}


First, the EC-H2020-SCC framework programme is based on the rationale that cities achieve more when they collaborate. The lighthouse projects share technical learning, spread the risk of investing in new technology, and use their scale to drive down costs through joint procurement. Technologies tested as part of the EC-H2020-SCC framework programme can then be implemented on a wider scale at a vastly reduced cost per unit. Evidence suggests that joint procurement can generate massive cost savings for cities bold enough to embrace inter-city cooperation. For instance, following a 2001 reorganisation of regional procurement in Austria, city authorities achieved savings of $30 \%$ and an administrative workload reduction of $60 \%$ [17].

Second, during the 2014-2019 period, 17 lighthouse projects-GrowSmarter, Remourban, Triangulum, Replicate, Sharing Cities, SmartenCity, Smarter Together, My Smart Life, Ruggedised, IRIS, Matchup, Stardust, Making City, City Exchange, Atelier, Pocityf, and Sparcs [13]—have been funded under the EC-H2020-SCC framework programme encompassing 46 lighthouse cities and 71 follower-fellow cities with the direct involvement of their related stakeholders. An overarching benchmarking analysis shows a wide range of city-networks, compositions, and budget allocations. Nonetheless, the rationale behind the formulation of replication strategy seems to follow the institutional discourse where the lighthouse cities command and entirely determine the replication procedure with very little active decision-making by follower-fellow cities. It is also true that there are nuanced differences among lighthouse projects. Whereas the first round of lighthouse projects (GrowSmarter, Remourban, and Triangulum) depict a rather mechanistic and unidirectional managerial understanding in how to proceed with replication, the rounds after SCC1-2014 have gradually evolved towards a more iterative or dynamic approach by (1) including follower-fellow cities much earlier in the process $[54,58-60,63,65,68]$ and (2) allowing their active involvement in the replication planning and outcomes through knowledge exchange activities such as workshops, thematic webinars, and interaction activities $[55,56,64,66]$.

Third, beyond the ongoing technical implementations and because they are hypothetical and not mentioned in lighthouse projects' replication-related formulations' analysis, this article highlights that, sooner than later, innovative technological solutions in the lighthouse projects will require attention to the inevitable consequences of data disruption of existing platforms [29,70]. As a result of the GDPR taking effect from May 2018, lighthouse and follower-fellow cities are required to include particular protocols by allowing citizens to avoid complicated (and often obscure) extractive algorithmic governance practices [71]. Failure to do so may mean bypassing the role of city stakeholders in filtering urban solutions from the techno-ethical perspective of data beyond complying with privacy standards, as requested by the GDPR [8]. There are already clear consequences for replication activities in terms of the current European digital economy that is being increasingly characterized by pervasive processes of datafication, with "big data" on citizens' behaviour collected by private companies without further democratic accountability [28]. However, the benchmarking conducted did not find any evidence yet of such harvesting in the replication strategies carried out by the lighthouse projects [72].

To sum up, the three takeaways, by which (i) technical learning and collaboration among cities, (ii) the evolution towards a more iterative or dynamic approach, and (iii) the inevitability to draw contextual attention to the algorithmic disruption, are critical for the core function of replication of smart cities; of particular emphasis is the fact that, in the post-COVID-19 landscape and due to the extensive developments of the GDPR, cities should foster learning processes from each other and avoid the temptation to conduct pure replication without filtering the urban interventions through the democratic accountability of a multi-stakeholder framework and the local expertise of knowledgeable city representatives. Having said that, by examining the EC-H2020-SCC framework programme's project documents [13-18] and, more specifically, those summarised in Table 1 about the remaining 16 lighthouse projects [53-68], little evidence is shown about the effectiveness and benefits derived from the pure replication transfer, at least for stakeholders or citizens [11]. In the near future, in addition to the need to protect citizens from the algorithmic disruption with the GDPR coverage, it is rather likely that increasingly bigger differences among cities, not only with similar socio-economic and technological 
infrastructure features but also with uneven resilient responses to the COVID-19 pandemic, will surface, a fact that inevitably will make replication even less feasible for mechanistically happening among smart cities.

\section{Research Question: Why Might Replication Not Be Happening among Smart Cities as a Unidirectional, Hierarchical, Mechanistic, Solutionist, and Technocratic Process?}

One of the most important challenges in implementing smart city policies is grasping the nature and procedure for replication dynamics in the current post-algorithmic smart city [10]. As such, while evidence, as analysed in the previous section, from the lighthouse projects suggests that the devil is often in the details - it is, at the same time, possible to identify common mechanisms that appear to hamper replication. According to Vandervyvere [36] (p. 7), replication is not happening as smoothly as anticipated by the EC-H2020-SCC because of the following five factors. First, there is a lack of connection between the replicating technology and the local stakeholders' interest. Second, the simplistic business-as-usual approach of the profit-driven private and the public sectors focused excessively on the short term [73]. Third, unique contexts are not seriously considered. Fourth, regulatory bottlenecks are still sustained by vested private interests and systemic inertia. Fifth, there is a lack of commitment from politicians in realising urban transformations. Of these, context is particularly important as the secret to effective replication lies in the proper combination of context-specific measures, on the one hand, and uniformity for scaling up, on the other. Thus, what should be treated as context-specific? Moreover, where can (should) the local context be transcended? In line with the hypothesis suggested by Vandervyvere [36], in this article, therefore, the research question sheds light on the alternative pathway jointly implemented by the six cities of the EC-H2020-SCC Replicate project through introducing their resulting City-to-City-Learning Programme that is currently being intensively used to formulate fellow cities' replication plans.

Replication has been broadly researched through different perspectives focusing on public management practices [31,32,35]. According to Walker, James and Brewer [35] (p. 1221), "replication is increasingly recognized as an important part of knowledge production in the social sciences, especially for experimental approach." However, replication is also discussed and undertaken, sometimes controversially, in many other disciplines. For instance, Jilke et al. [32] clearly argue that there are good reasons to believe that replication may not always work as anticipated or designed by policy frameworks due to the difficulty in measuring a comprehensive equivalence in replications of experiments.

More specifically, by providing more examples from the project documents [13-18], it is noteworthy that replication methodologies applied in the EC-H2020-SCC framework programme by lighthouse projects, such as the one by Remourban [67], resonate with the idea of designing a list of indicators that pre-define the main features of cities through data sources, where to find this information, and the statistical procedures to be conducted to obtaining a classification of cities' typologies [74]. This project used a cluster identification tool for collecting 41 indicators to feed the lighthouse cities' supply and follower cities' demand as entirely separated procedures. Similarly, the Triangulum project acknowledges that their focus is only on the lighthouse cities [61], thus remaining relatively non-committal about the adoption by the follower-fellow cities [75]. Based on this technocratic-mechanistic approach, several replication techniques are suggested, including best practices, common cross-domain use cases, capability models, benchmarking and Key Performance Indicators (KPIs), interoperability, platform approach, standard (vertical and horizontal), and profiling. As such, the replication function in the EC-H2020-SCC was initially expected to increase innovation and technological transfer. It required finding suitable financing that was allied with innovative business models while sharing knowledge, good practices, and lessons learned to achieve a successful replication. The complexity of such a task makes simple copy-paste replication rare and difficult. That was the case also for GrowSmarter [62] adopting a unidirectional model by which twelve thematic groups entirely aligned with lighthouse cities developed smart solutions to be, thereafter, tested and adopted directly 
by the follower cities. It is noteworthy that the remaining lighthouse projects reoriented replication strategies [53-60,63-66,68] by including the agency of follower or fellow cities through knowledge exchange activities. The project documents and websites provide synthetic information from which we can draw such a preliminary conclusion.

In light of the brief benchmarking of the EC-H2020-SCC framework programme's lighthouse projects to overcome their failures and provide a readjustment to its initial approach, this article suggests that replication may well be re-designed as a blend of elements consisting of a learning process implemented from the social innovation perspective using fieldwork action research that includes the following: (1) examine in-depth the technological solution and, even, experimenting and prototyping to assess its potential for replication by local stakeholders (as a whole or partially); (2) adapt the intervention to local regulatory and socio-economic conditions; (3) include non-technical aspects that could be hindering replication, such as financing opportunities, the economic situation, regulatory regimes, social acceptability, business and social model adoption, algorithmic disruption, data ownership and privacy; and (4) ultimately, offer an operational framework where city representatives could well coordinate their learning process by including a wide range of stakeholders that could directly interact with other stakeholders operating within the same EC-H2020-SCC lighthouse project. This operational framework in EC-H2020-SCC Replicate project was the City-to-City-Learning Programme.

Thus, to provide not only a critical but also a constructive alternative to the given institutional definition of replication, as designed by the EC-H2020-SCC, this article illustrates this approach by suggesting a transition from the former approach to the one implemented in the Replicate project by using the social innovation perspective (Table 2). Thus, the function of replication seemed to have been projected, from the policy designers and practitioners simulating such a unidirectional, hierarchical, mechanistic, solutionist, and, even, technocratic procedure among smart cities, as Morozov described $[9,34,75,76]$. Instead, the City-to-City Learning Programme alternatively operated by following a social innovation perspective, thus considering the unique combination of multiple stakeholders in each Replicate city (regardless of being a lighthouse or follower-fellow) and, more importantly, the way replication could be effectively facilitated through a city network's multidirectional, radial, dynamic, iterative, and democratic learning process $[24,45,77,78]$.

Table 2. Conceptual evolution of replication from the social innovation perspective: Five Transitions. Source: www.replicate-project.eu/city2citylearning.

\begin{tabular}{cc}
\hline \multicolumn{2}{c}{$[21,41-44]$} \\
\hline From (Pure) Replication & To City-To-City-Learning \\
\hline Unidirectional & Multidirectional \\
\hline Hierarchical & Radial \\
\hline Mechanistic & Dynamic \\
\hline Solutionist & Iterative \\
\hline Technocratic & Democratic \\
\hline
\end{tabular}

Furthermore, this article provides further identified evidence about the replication strategy narratives of the remaining 16 lighthouse projects that complement Table 1: (i) GrowSmarter followed an Integrated Management Cycle purely with no explicit evidence about follower cities' engagement; (ii) Remourban implemented a roadmap model based on a supply and demand unidirectional model; (iii) Triangulum preliminary showed in the website a replication tool (currently unavailable), which stored the smart solutions achieved by the lighthouse cities; (iv) Sharing Cities acknowledged in its project document that follower cities were included at very early stages in the definition and design of the lighthouse projects, despite the fact that follower cities were meant to replicate the lighthouse solutions [68] (p. 6); (v) SmartenCity focused (in the same direction of Replicate) on considering the paradigm of city networks as crucial actors to address the challenges since it can create opportunities 
for peer-to-peer learning as the source of replication and innovation [66] (p. 15); (vi) Smarter Together examined in-depth organisational, legal, economic, and communication aspects in the lighthouse cities to reproduced urban solutions in the follower cities based on the former examination [63] (p. 4); (vii) My Smart Life incorporated knowledge exchange activities such as workshops, study tours, and webinars to the process by which lighthouse cities shed light on the replication action to the follower cities [65]; (viii) Ruggedised suggested knowledge sharing and training and the establishment of an initial assessment of the follower cities as a way to implement replication strategies [58]; (ix) IRIS addressed replication by scaling the solutions both inside and outside the consortium through a knowledge exchange framework and their assessment through KPI (Key Performance Indicators) [64]; (x) Matchup implemented replication through events and a comparative analysis of indicators of lighthouse cities without explicitly delineating the role of the follower cities within this process [56]; (xi) Stardust, in its current stage of development, seems to focus on a holistic view about replication but has not yet explicitly detailed the role of the follower cities [60]; (xii) Making City detailed its replication strategy by entirely maximising the Positive Energy Districts (PED) in their six follower cities [55]; (xiii) the City Exchange project formulation on replication strategy is rather generic with no explicit procedure about how this replication will take place within the five follower cities [54]; (xiv) Atelier [53] and (xv) Pocityf [57] have yet to define any replication strategy; and (xvi) Sparcs [59] refers to urban energy transformations from lighthouse cities to fellow cities.

According to Mihci [42] (p. 1), given the problem of the social innovation perspective and, also, the function of replication, "it is the difficulty to obtain reliable results through metrics that could be extended to the statistical, methodological, and, even, conceptual spheres." Nonetheless, this article adopts the social innovation perspective of empowering networks of stakeholders suggested by Pel et al. [44] for the conceptual evolution of replication, as conducted in the EC-H2020-SCC Replicate project's City-to-City Learning Programme. This programme, stemming from the social innovation perspective, produced objective results directly from the interaction of six Replicate cities' stakeholders that are currently being used internally by fellow cities to formulate collaboratively their own replication plans. The replication function actually has proven the requirement to be connected with local contextual ecosystems of stakeholders to better adopt the suggested and agreed upon urban interventions [41]. In line with the DNA of the resulting City-to-City Learning Programme in the Replicate EC-H2020-SCC lighthouse project, Bartels [22] argues that social innovation now can play an active role in bolstering transformative change and create a trajectory for learning for smart cities and their urban governance [79]. This article offers an operational alternative through a conceptual evolution of the understanding and implementation of replication in the given institutional corpus of EC-H2020-SCC in the specific Replicate project through five transitions stemming from a multiple stakeholder-driven, socially innovative perspective. The key transitions are (1) from a unidirectional to a multidirectional perspective, where six Replicate cities shared their best practices and lessons learned at the same level; (2) from a hierarchical logic to a radial one; (3) from a mechanistic understanding of replication to a dynamic, flexible, and agile one; (4) from the almost obligatory requirement to finding urban solutions to an ongoing iterative process of pinpointing causes and alternative prototypes for solutions; and, (5) ultimately, creating a more democratic ecosystem realized with a wide range of stakeholders, unlike a technocratically directed outcome.

The employed fieldwork action research method was based on the research data collected during preparation and through the webinar series called City-to-City Learning Programme. The data was co-produced and co-analysed with each city (either lighthouse or fellow) representative. The fieldwork action research method [38,39] allows the study to maximise the transition and to experiment from the pure replication approach to the resulting city-to-city-learning outcome. The data was analysed consistently with the six city representatives of San Sebastian, Essen, Florence, Lausanne, Bristol, and Nilüfer during the whole programme from January to December 2019. Above all, the five transitions anchored this fieldwork action research experimentation. Before, during, and after every webinar series, information was effectively shared with each city representative to foster a multidirectional, 
radial, dynamic, and iterative process. Alongside this, each city representative shared among its city-regional stakeholders' network the outcome of the webinars and the lessons learnt. It goes without saying that the main and direct beneficiaries of this action research method were fellow cities. As it was already presented in the Introduction section, the objective of this method, and thus, of this article, was to show an alternative replication pathway that could assist fellow cities in learning and adapting from the other cities' actions, measures, and prototypes that may well be included in their replication plans. Table 3 will show the ongoing status of their replication plans that will be effectively finalised by December 2020 by the three city representatives of the fellow cities. Thus, the method used (and built) through action research resulting in the City-to-City Learning Programme is the proof that demonstrates that another replication rationale may be feasible and beneficial for the whole consortium. Moreover, there are several indirect benefits of this action research process that are worth highlighting as follows (Table 3): (i) the impact achieved both internally and externally, (ii) the stakeholders directly involved in the online and offline discussions, and (iii) the selected actions to be replicated, scaled up, and adapted, subject to the fellow cities' replication plans. 
Table 3. Replication Plans: Scalability, adaptability, and singularity. Source: www.replicate-project.eu/city2citylearning.

\begin{tabular}{|c|c|c|c|c|c|c|c|c|c|c|c|c|c|c|c|c|c|c|c|c|c|}
\hline \multirow{3}{*}{$\begin{array}{l}\text { Replicate } \\
\text { Cities }\end{array}$} & \multirow{3}{*}{$\mathrm{L} / \mathrm{F}\left(^{*}\right)$} & \multirow{3}{*}{$\begin{array}{l}\text { Smart } \\
\text { City } \\
\text { Action }\end{array}$} & \multicolumn{2}{|c|}{$\underset{(* *)}{\operatorname{Impact}}$} & \multicolumn{5}{|c|}{$\begin{array}{c}\text { Stakeholders Directly Involved: } \\
\text { Identified through Penta Helix Multiple Stakeholders' } \\
\text { Policy Framework }\left({ }^{* * *}\right)\end{array}$} & \multicolumn{12}{|c|}{$\begin{array}{l}\text { Potential Fellow Cities' Replication Plans }(* * * *) \text { : } \\
\text { Selected Actions to Be Replicated, Scaled Up, and Adapted }\end{array}$} \\
\hline & & & \multirow{2}{*}{$\mathbf{P}$} & \multirow{2}{*}{$\mathrm{V}$} & \multirow{2}{*}{$\frac{1}{\text { Public }}$} & \multirow{2}{*}{2} & \multirow{2}{*}{ Academia } & \multirow{2}{*}{$\frac{4}{\text { Civil Society }}$} & \multirow{2}{*}{ 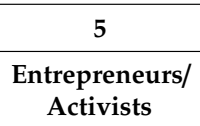 } & \multicolumn{4}{|c|}{ Essen } & \multicolumn{4}{|c|}{ Lausanne } & \multicolumn{4}{|c|}{ Nilüfer } \\
\hline & & & & & & & & & & E & $\mathbf{M}$ & I & C & E & $\mathbf{M}$ & I & $\mathrm{C}$ & $\mathbf{E}$ & $\mathbf{M}$ & I & C \\
\hline \multirow{3}{*}{$\begin{array}{l}\text { (SS) } \\
\text { San } \\
\text { Sebastian }\end{array}$} & \multirow{3}{*}{$\mathrm{L}$} & SS.1. & \multirow{3}{*}{30} & \multirow{3}{*}{149} & $x$ & $x$ & & & & $x$ & & & & $x$ & & & & & & & \\
\hline & & SS.2. & & & $x$ & $x$ & & & & & & & & & & & & & & & \\
\hline & & SS.3. & & & $x$ & $x$ & & & & & $x$ & & & & $x$ & & & & & & \\
\hline \multirow{3}{*}{$\begin{array}{l}(\mathrm{E}) \\
\text { Essen }\end{array}$} & \multirow{3}{*}{$\mathrm{F}$} & E.1. & \multirow{3}{*}{22} & \multirow{3}{*}{33} & $x$ & $x$ & $x$ & & $x$ & & & & & & & & & $x$ & & & \\
\hline & & E.2. & & & $x$ & $x$ & & & $x$ & & & & & & & & & & & & \\
\hline & & E.3. & & & $x$ & $x$ & & & & & & & & $x$ & & & & & & & \\
\hline \multirow{3}{*}{$\begin{array}{l}(\mathrm{F}) \\
\text { Florence }\end{array}$} & \multirow{3}{*}{$\mathrm{L}$} & F.1. & \multirow{3}{*}{35} & \multirow{3}{*}{40} & $x$ & $x$ & $x$ & & $x$ & $x$ & & & & & & & & & & & \\
\hline & & F.2. & & & $x$ & $x$ & $x$ & & & & $x$ & & & & $x$ & & & & & & \\
\hline & & F.3. & & & $x$ & $x$ & $x$ & & $x$ & & & & & & & & & & & & \\
\hline & & L.1. & & & $x$ & $x$ & & $x$ & $x$ & $x$ & & & & & & & & & & & \\
\hline $\begin{array}{c}\text { (L) } \\
\text { Lausanne }\end{array}$ & $\mathrm{F}$ & L. 2 . & 10 & 20 & $x$ & & & & $x$ & & & & & & & & & & & & \\
\hline & & L.3. & & & & & & $x$ & $x$ & & & & & & & & & & & & \\
\hline & & B.1. & & & $x$ & & $x$ & & $x$ & & $x$ & & & & & $x$ & & & $x$ & & \\
\hline $\begin{array}{c}\text { (B) } \\
\text { Bristol }\end{array}$ & $\mathrm{L}$ & B.2. & 23 & 40 & & & $x$ & & $x$ & & & $x$ & & & & & & & & $x$ & \\
\hline & & B.3. & & & $x$ & & $x$ & $x$ & & & & & $x$ & & & & $x$ & $x$ & & & $\mathrm{x}$ \\
\hline & & N.1. & & & $x$ & & $x$ & $x$ & & & & & & & & & & & & & \\
\hline $\begin{array}{l}(\mathrm{N}) \\
\text { Nilüffer }\end{array}$ & $\mathrm{F}$ & N.2. & 30 & 18 & $x$ & & $x$ & $x$ & $x$ & & & & $x$ & & & & & & & & \\
\hline & & N.3. & & & $x$ & $x$ & & & $x$ & & & & & & & & & & & & \\
\hline
\end{tabular}

${ }^{*}$ L represents lighthouse cities and $\mathrm{F}$ does fellow cities. ${ }^{* *} \mathrm{P}$ represents the number of participants during the session and $\mathrm{V}$ represents the number of offline views. ${ }^{* *}$ The Penta Helix framework [49] distributes stakeholders in five categories: 1 represents the public sector, 2 represents the private sector, 3 represents academia, 4 represents the civil society, and 5 represents social entrepreneurs and activists. **** This column depicts the identification made by fellow cities' representatives in the General Assembly that took place in Florence on 30 October 2019. social entrepreneurs and activists. **** This column depicts the identification made by fellow cities' representatives in the General Assembly that took place in Florence on 30 October 2019.
The potential fellow cities' replication plans have effectively selected these smart city initiatives in close collaboration with stakeholders of the Replicate cities, regardless of being lighthouse or fellow cities. E represents smart city initiatives related to energy, M represents mobility, I represents ICT, and C represents citizens' engagement. The black area means that each fellow city cannot replicate itself 


\section{Results: City-To-City Learning Programme in the EC-H2020-SCC-Replicate Project}

The design of the City-to-City Learning Programme as the main replication strategy of the EC-H2020-SCC Replicate project was initiated from the beginning of the project in February 2016. Since then, the three lighthouse cities (San Sebastian, Florence, and Bristol) and the three fellow cities (Essen, Nilüfer, and Lausanne)—replacing the former nomenclature and the hierarchical position of the follower cities-closely collaborated in the definition of the contents and the methodological activities involved (Figure 1). In doing so, the function of replication within the project intensively encouraged a fertile dialogue, thus connecting stakeholders (regardless of their lighthouse or fellow city consideration) working either in one or, sometimes, several smart policy sectors (energy, mobility, and ICT). Furthermore, this experimental approach resulted in a productive conversation among stakeholders in the six cities. The replication strategy previously examined the unique multiple stakeholder framework in each fellow city through the Penta Helix (including actors interacting in the public, private, civil society, academic, and entrepreneur-activist domains of smart cities) $[49,80]$.

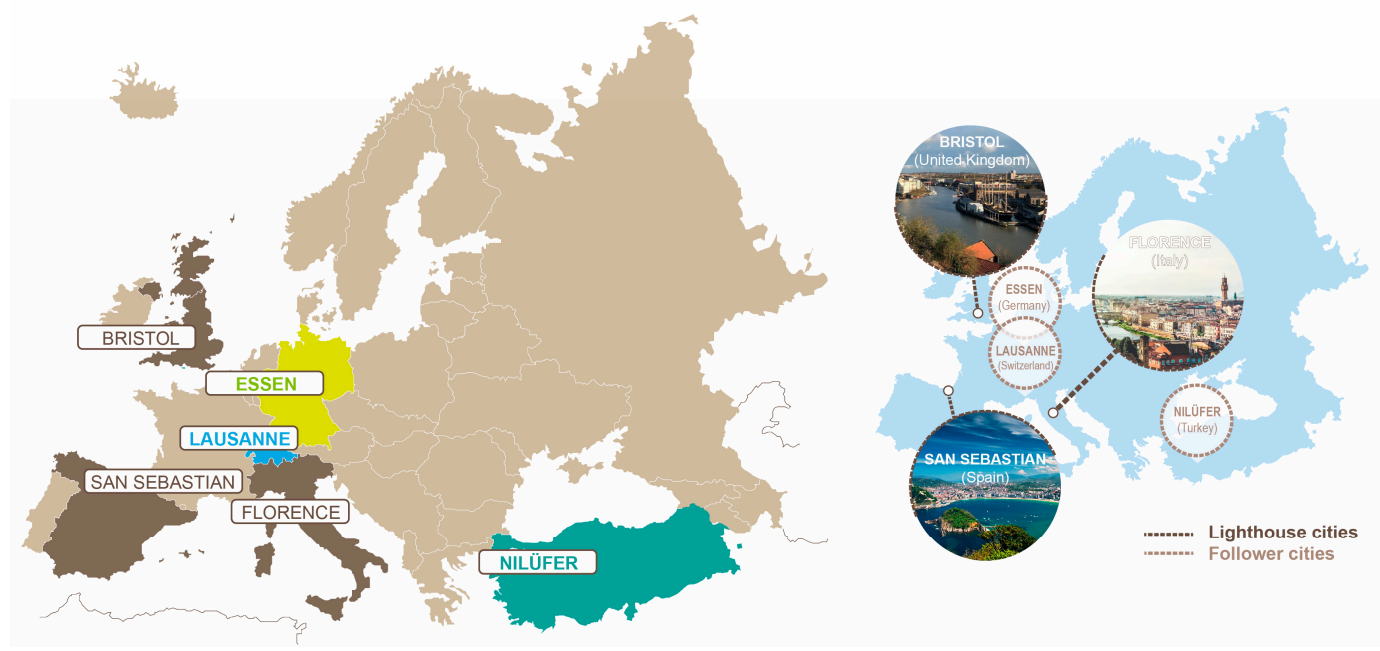

Figure 1. EC-H2020-SCC Replicate project.

Wisely influenced by the research and policy findings conducted by the Urban Transformations ESRC (Economic and Social Research Council) Programme at the University of Oxford [81], the fieldwork action research conducted until December 2019 allowed the author to anticipate the cleavage between the smart city as a mobile policy understood as "glossy stories, fragmented processes, and a random process" [82] (p. 133), and the early entrepreneurial research findings at the beginning of the Replicate project by deconstructing a somewhat techno-deterministic smart city policy agenda. Consequently, the Replicate project's strategy primarily focused on putting methodological advancements into action to foster learning in and among cities by avoiding (and presumably overcoming) replicability dependent on techno-deterministic principles based on so-called solutionism [40]. Smart cities are not machines [83]. Moreover, their internal initiatives are directly and proportionally dependent on stakeholders interacting uniquely with a dense set of power relationships [50]. How should such a complex strategy called Replication be approached [17]?

In this Results section, this article describes, in depth, the smart city actions implemented by each city in the EC-H2020-SCC Replicate project. In doing so, this article objectively presents how fellow cities in the EC-H2020-SCC Replicate project are elaborating and shaping their replication plans, widely adapting, and prototyping smart city actions conducted not only in the lighthouse cities but also in the other fellow cities. Judging from Table 3, and particularly from the Discussion section, replication in the EC-H2020-SCC Replicate project is not being facilitated as a unidirectional, hierarchical, mechanistic, solutionist, and technocratic process. Instead, and this is the main objective of this article, the EC-H2020-SCC Replicate project, altogether, among the six Replicate cities, attempted 
to open up an alternative experimental pathway following a social innovation perspective. In doing so, this article objectively interprets this alternative replication process that is currently taking place as a learning process rather than as pure replication. Thus, replication may be happening among the six cities of the EC-H2020-SCC Replicate project, but, most importantly, not as it was unidirectionally anticipated through a pure replication from lighthouse cities to fellow cities (former follower cities). The learning process following the five transitions presented in the previous section as the main guiding element in this replication process. Consequently, this section, Results, shows the following evidence-based and objective policy content: How fellow cities are currently shaping their potential replication plans as an ongoing process. Methodologically speaking, it is worth noting that the essence of the fieldwork action research stemming from the social innovation perspective implemented in the EC-H2020-SCC Replicate project is eminently an iterative and qualitative mixed method [38,39].

The fieldwork action research method is described, in depth, as follows: Within the first three years of the project, covering the 2016-2018 period, the three lighthouse cities focused entirely on their pilot initiatives in the three smart city sectors (energy, mobility, and ICT). Alongside these initiatives, the Replication strategy suggested reverting the rationale for the mainstream approach (preliminarily designed by EC policymakers), stemming from a unidirectional and mechanistic logic. By contrast, the Replicate project was gradually empowering the former follower cities (now already officially and institutionally fellow cities) by putting them at the same level as the lighthouse cities through a multidirectional learning cycle. Until 2019, an intense fieldwork action research process alongside the lighthouse cities' initiatives in three fellow cities for those early three years was carried out, including (1) critical factors' assessment and (2) mapping out the unique composition of stakeholders by following the Penta Helix policy framework [49]. Essentially, the programme was based on the following methodological steps: (1) The singularity of each city (strategic aim and contextual factors) was examined through a critical factors' assessment methodology, with (2) the scalability depending on the composition of the multiple stakeholders' policy scheme, such as their interdependence and power relations (examined through the Penta Helix policy framework). Moreover, (3) the adaptability of the given smart action (contrasting feasibility and potential impact) was facilitated through this City-to-City Learning Programme; and, ultimately, (4) the replicability after the multidirectional learning loop among stakeholders through each fellow city's action-driven formulation was established, completing their own replication plans tailored to their strategic and operational needs.

As a result, the City-to-City Learning Programme set the scene to establish a prolific common ground among the six Replicate cities without any hierarchical or functional distinctions. The stakeholders fostered a shared participatory agora and a co-operative platform directly among Replicate stakeholders (regardless of their city of reference). Funnily enough, and most importantly, the Replicate project curated and warmed-up this programme with the active participation of the representative and strategic stakeholders of the six Replicate cities by experimenting with the complex task of replication through a multidirectional learning loop stemming from an approach using social innovation.

Ultimately, this programme was designed to assist fellow cities in formulating their own replication plans, outlined in Part 4 of this article. Drawing on the experience and objective results achieved and publicly available at www.replicate-project.eu/city2citylearning-more than 150 registered participants and almost 300 offline views - this section addresses how this replication strategy and intervention, stemming from a perspective of social innovation, developed new forms of policy incentives for more participatory policy design, as well as monitoring, feedback, assessment, and learning loops that utilize the characteristics of digital transformations in smart cities among a vast and nuanced democratic representation of stakeholders' plurality and diversity.

This section provides an analytical summary of the fieldwork action research conducted for the elaboration of the City-to-City Learning Programme encompassing a series of six webinar sessions in which each Replicate city elaborated on its smart city strategic actions (organized through three slots per city by including a diverse range of stakeholders). It was presented and discussed directly among Replicate stakeholders, thus ensuring a multidirectional, radial, dynamic, iterative, and intentionally 
more democratic learning process by bypassing the given pure mechanistic approach suggested by the EC-H2020-SCC framework programme.

\subsection{San Sebastian}

San Sebastian, as the leading lighthouse city of the Replicate project, was the first city to participate in the webinar programme. The session led by the city representative of San Sebastian, entitled Excellence of Service Provision Based on Data Monitoring and Smart Management, took place on 5 February 2019 [84].

The city profile and characterisation of San Sebastian in the context of the Replicate project can be summarised as follows: The municipality of Donostia-San Sebastian is the capital of the Province of Gipuzkoa in the autonomous Basque community in the northern region of Spain. It has a population of 186,000 people. Within the context of the Replicate project, several pilot projects were planned in the area of the Urumea river district. The district has the city's largest green park, Ametzagaña Park, and a large industrial park, Poligono 27, which houses over 300 companies employing almost 4500 people. More dramatically though, it has also been a district in the city vulnerable to flooding from the river, which is a problem that has gradually been addressed through the Replicate project. One challenge the Replicate project attempted to tackle in this neighbourhood was improving the district's connectivity to the rest of the city through public transport, public lighting, Internet connectivity via a high-speed network, and the energy efficiency of its buildings. This district was the target of many measures to improve the quality of life, including the construction of approximately 1500 new homes in a new neighbourhood, building a district heating plant, and installing a smart lighting system.

The City-to-City Learning Programme session for San Sebastian consisted of three smart city presentations subject to be replicated by the fellow cities involving a diverse set of stakeholders-representing primarily the public, private, and academic sectors applying the Penta Helix framework [49]. The first presentation revolved around the transition from traditional infrastructures to intelligent connected solutions for smart lighting implemented by the local Small and Medium Enterprise (SME), Leycolan [85] (SS.1.). This urban intervention allowed for communication between luminaries. The second presentation aimed at exploiting the city's information by linking data to other cities through the semantic web executed by the ICT firm, Eurohelp [86] (SS.2.). The information is part of the Linked Open Data Cloud, published as open data under the linked data paradigm. Finally, the third presentation showed a smart platform developed by the local firm, Ikusi [87] (SS.3.), that aimed at integrating the city's mobility data sources.

\subsection{Essen}

The second session of the programme, The New Smelters of the Coal Heartland, was led by the city representative of the fellow city of Essen and took place on 21 March 2019 [88].

The City of Essen is located in the North-Rhine Westphalia, in the heart of the Ruhr Area, with approximately 5.1 million people. Following London and Paris, this metropolitan area constitutes the third-largest urban agglomeration in Europe. Essen is an independent city in the administrative district of Düsseldorf. Its 582,624 inhabitants make it the ninth-largest city in Germany. Essen has transitioned from being a coal and steel metropolis to a European Green Capital. The municipal area of $210 \mathrm{~km}^{2}$ is divided into nine districts and 50 neighbourhoods. Essen is an important industrial centre for German enterprises. A mix of big firms, SMEs, and an active craft sector maintain a good economic climate. There is a very comprehensive relationship of the European Green Capital 2017 project with Essen's goal to establish a smart city strategy from the Replicate project.

The City-to-City Learning Programme session for Essen was represented primarily by the public, private, academic, and entrepreneurial and start-up sectors. The first presentation described how the support of start-ups could help blend the smart and sustainable agendas of cities, as in the case of Camp-Essen [89] (E.1.). Camp-Essen was presented as a platform for collaboration and co-innovation among start-ups, corporations, SMEs, business angels, and academia in line with the Penta Helix policy scheme [49] employed for the whole replication strategy. The second presentation presented by the 
socially-driven entrepreneurial Non-Governmental Organisation (NGO), Impact Hub Ruhr [90] (E.2.), aimed at connecting communities for change and how the start-up scene can help blend the smart and sustainable agendas of cities. Impact Hub Ruhr complemented Camp-Essen by connecting social entrepreneurs with a broadband of active citizens. Impact Hub Ruhr was actually presented as a global network focused on building entrepreneurial communities out of innovators, social entrepreneurs, and urban intermediaries [47]. The final action elaborated on how a brownfield could turn into a showcase for the smart and sustainable future of cities by presenting the flagship project, Essen 51, led by a private firm called Thelen Gruppe [91] (E.3.). This new district is being built with a forecast of 1500 new homes and 500,000 $\mathrm{m}^{2}$ of new business space.

\subsection{Florence}

The third session of the programme, Go Fast, Go Green, Get Connected: That's Smart!, was led by the city representative of the lighthouse city of Florence and took place on 7 May 2019 [92].

Florence, the capital of the Italian region of Tuscany, is the region's most populous city. It has approximately 383,000 and over 1 million inhabitants in the core and greater metropolitan area, respectively. Due to its historical and cultural heritage, tourism is its most important industry. However, production and commercial activities remain important economic drivers, especially in the greater metropolitan area. The city is often in the top ten most visited cities in the world, with approximately 10 million tourists staying in local accommodation. About two million more visitors arrive through cruise ships and day-tours. This high number of visitors presents a significant challenge for the city's administration. While it represents the main source of income for the city, it is also increasingly seen as a threat to its services and management, as well as the quality of life for those who live in the highly congested central urban zones. Within the context of the Replicate project, the smart city pilot projects were implemented in the district of Novoli, northwest of Florence.

The City-to-City Learning Programme session for Florence was represented primarily by the public, private, civil society, academic, and entrepreneurial sectors. The first presentation revolved around the fast recharge and e-taxi examples of e-mobility initiatives to deploy sustainable mobility presented by the company, e-distribuzione [93]. Florence has been undertaking transport network modernisation from 2016 to 2020, thus increasing the number of electric vehicles, doubling the number of hybrid-electric vehicles, and reducing the number of pure internal combustion engine vehicles to as low as zero (F.1.). The second presentation covered an e-recharge system, facilitating the move towards a sustainable community (F.2.). Florence aimed at promoting the development of electric mobility through the realisation of a recharging network for electric vehicles. Finally (F.3.), the third presentation was primarily developed by the University of Florence around the smart city platform and the control room.

\subsection{Lausanne}

The fourth session of the programme, Roadmap for the Realisation of an Eco-District, including the Development of Medium-Depth Geothermal Energy in Urban Areas, was led by the city representative of the fellow city of Lausanne and took place on 9 July 2019 [94].

Lausanne is the fourth biggest city in Switzerland. It has 142,000 inhabitants and is the centre of an urban area with a population of 350,000. The Gross Domestic Product (GDP) per capita is about 61,000€ in 2015. Its main firms are SICPA, Bobst, Tetrapack, and Logitech. In 2016, Lausanne launched an energy efficiency programme called Equiwatt, as a part of the 2050 federal energy strategy. It is aimed at saving energy for individuals and businesses, thereby raising awareness of energy consumption. In the mobility sector, Lausanne has been striving for many years to limit the overwhelming space taken up by private cars to encourage more access to shops and businesses. By reducing authorized parking times on the streets, the municipality encourages commuters to leave their vehicles at outlying Park \& Ride facilities. Private car traffic has been reduced by 6000 vehicles per day. ICT is a significant issue for Lausanne, as highlighted by stakeholders in the city. 
The City-to-City Learning Programme session for Lausanne was represented primarily by the public, private, and academic sectors: The first presentation covered a roadmap for the realisation of the eco-district, called Plaines-du-Loup (L.1.). This district promotes the attractiveness by introducing a functional mix (30\% activity, 70\% housing) and the creation of a public transport axis. The second presentation covered the development of medium-depth geothermal energy in the Plaines-de-Loup district (L.2.). In this district, heat production was based on deep geothermal and heat recovery from wastewater. Finally, the third presentation was devoted to the energy programme called Equiwatt (L.3.).

\subsection{Bristol}

The fifth session of the programme, Collaborating with Communities: Creating the Future Cities We Need, was led by the city representative of the lighthouse city of Bristol on 26 September 2019 [95].

A recent performance assessment framework on Bristol's smart city strategy [96] stated that the strategy was formed in 2011 to lead the digital innovation agenda within the city. Two main landmark projects are detailed as the key performance of this city: the Bristol is Open and Replicate project. Research and policy findings reveal two main and optimistic conclusions for the case of Bristol [96] (p. 6). First, "Bristol presents an increasing effort to experiment with the citizen-centric approach, [considering] (smart) citizens as decision-makers rather than pure data providers." Second, "Bristol is ultimately amalgamating a large number of smart projects in a complex network of interactions with citizens. The prospect for the future will be fostering decision-makers' interplay, [thus] portraying the city as an open platform."

The City-to-City Learning Programme session for Bristol was represented primarily by the public, academic, and civil society sectors. The first presentation delivered Bristol's methodological approach to co-design urban interventions with citizens (B.1.) [97]. According to its strategic stakeholder, KWMC [98], Bristol's approach put local needs at the heart of innovation; that is, tech is pulled in, not pushed onto citizens. The second presentation revolved around technology, data, and governance. Particularly, how we make it accessible for citizens embodied by the flagship project Bristol is Open. Data that could affect a city planning project-such as air quality, traffic rates and patterns, energy consumption, and crime statistics—was shown through open data platforms of the city (B.2.). Finally, the third presentation emphasised the ongoing project called the One City Approach and Inclusive Futures. The presentation was, essentially, a shared city vision by 2050 based on six prioritized themes: health and well-being, economy, homes and communities, environment, learning and skills, and connectivity (B.3).

\subsection{Nilüfer}

The final session of the programme, Socio-Economic Development from Below, was led by the city representative of the fellow city of Nilüfer and took place on 20 November 2019 [99].

Nilüfer is one of the 17 districts of Bursa province, located in a key geographic position providing a logistic connection for major cities, such as Ankara, İstanbul, and İzmir, to equally access national and global markets. Three universities offer world-class education. Advanced infrastructure, dynamic entrepreneurs, and high quality of life and work create an attractive investment as well as a welcoming social climate. It has been established as the main residential development area of Bursa to meet the housing needs of the growing city as well as industrial and commercial structures. Nilüfer comes first among the districts of Bursa in terms of the economic contribution while providing employment opportunities to $80 \%$ of the Bursa population via the Organized Industrial Zones within its border. In 2015, the population of Nilüfer Municipality reached 397,303, a 5.81\% increase over the previous year. The population increase in the last five years was 35\%. This growth is higher than the average of Turkey and Bursa and will probably continue to grow due to the city's attractive industrial investment and jobs. The population of Nilüfer encompasses $13.98 \%$ of the total population of Bursa $(2,842,547)$. Nilüfer had $495.75 \mathrm{~km}^{2}$ of district area and 962 persons $/ \mathrm{km}^{2}$ in 2015, while these values were 10,886 $\mathrm{km}^{2}$ and 273 persons $/ \mathrm{km}^{2}$ for Bursa, respectively. Bursa is viewed as one of the fastest-growing 
middle-weight cities that are projected to account for more than $60 \%$ of global GDP growth over the next 15 years. There are 16 organised industrial zones and one free trade zone with clusters in automotive, textile, machinery, food, and furniture.

The City-to-City Learning Programme session for Nilüfer was represented primarily by the public, private, academic, civil society, and emergent entrepreneurial activities and sectors. The first presentation addressed grassroots empowerment through neighbourhood committees that were created in 2009 to reach disadvantaged segments in society (N.1.) [100]. The second presentation covered bottom-up energy efficiency, including initiatives for energy cooperatives, grey water treatment and compost facilities, and a social entrepreneurship centre (N.2.). Finally, the third presentation covered emerging industrial spin-off ecologies related to the paradigm of industry 4.0 and advanced manufacturing (N.3.).

\section{Discussion: Shaping Potential Fellow Cities' Replication Plans}

As a result of the City-to-City Learning Programme, a broad amalgamation of smart city actions interdependently touching upon smart sectors, such as energy, mobility, ICT, and citizens' engagement, and, more importantly, deeply discussed among a wide range of Replicate stakeholders, was offered to fellow cities to formulate their own replication plans. Table 3 summarises the outcome of the learning process among stakeholders, resulting in a strategic replication formulation framed by the general context of the City-to-City Learning Programme, which finished in December 2019. As has already been presented in the third section of this article, the method based on fieldwork action research allowed the project to assist fellow cities in currently formulating their replication plans as follows:

Essen concluded by considering the lessons learned for replicating the following smart city initiatives, organised by sectors involving both lighthouse or fellow cities and the related stakeholders. (1) In energy, smart public lighting, intelligent LED systems, and an e-taxi system would be adopted directly, learning from stakeholders in San Sebastian and Florence. Improvements to the public lighting infrastructure would include innovative solar thermal seasonal storage (for social housing). Moreover, Essen will attempt to incorporate the energy planning of an eco-district for Essen 51, learning directly from the Plaines-du-Loup district carried out by the fellow city of Lausanne. (2) In the case of mobility, Essen expressed its interest in adopting electric buses and an e-bike sharing system, as deployed by the smart mobility platform of the lighthouse city of San Sebastian. Additionally, the info-mobility system developed by the lighthouse city of Florence offers a comprehensive information system across services, full electric taxi vehicles, fast recharging systems, and a sustainable public taxi fleet. Finally, the journey planner and parking apps (including payment), developed by the lighthouse city of Bristol, was decided to be an appropriate model. (3) In the area of ICT, Essen may adopt the model of Bristol is Open, which would drive social collaboration, knowledge, data sharing, and analytics management across the digital landscapes to deliver services to the public authorities, residents, business, students, and visitors. Finally (4), in the area of citizens' engagement, Essen showed a particular interest in emulating the One City Approach and Bristol is Open (particularly through its Citizen Sensing initiative), and the bottom-up energy efficiency measures adopted in Nilüfer, which directly connects with the approach of involving multiple stakeholders in Essen.

Lausanne concluded with its own list of potential actions after being matched with several interventions conducted by the following Replicate cities. (1) In energy, in line with the core value proposition put forth by Lausanne around the district heating intervention, the demand-side platform developed in the St. Sebastian and Essen 51 interventions drew special attention in combination with the public smart lighting system deployed in St. Sebastian. (2) In mobility, Lausanne may be adapting the smart transport management system developed in St. Sebastian and showed interest in learning from the experience in Florence regarding the taxi fleet with electric vehicles and the superfast recharging system. (3) In the ICT sector, the Bristol is Open approach could be adapted in Lausanne, (4) as well as for citizens' engagement with the One City Approach of Bristol. 
Ultimately, Nilüfer is likely to implement the following initiatives. (1) In energy, it aims to expand the renewable energy cooperatives (also called as energy communities), led by Camp-Essen. In addition to this, Nilüfer showed interest in adapting the smart homes model related to the smart residential demand response that was implemented in the One City Approach in Bristol. (2) In mobility, Nilüfer learned about the ParkUS parking model that is related to the Open Data Movement in Bristol. Additionally, an adaptation of smart e-bike rental solutions developed by the SME Co-Wheels could be well attempted in Nilüfer by re-contextualising methodologies to co-design mobility alternatives with citizens. (3) In the ICT sector, Nilüfer requested information to scale up the policy framework known as Bristol is Open. (4) Finally, the intensive investment that is being made in Nilüfer in citizen engagement may be reinforced through the lessons from the Bristol One City approach concerning offering a systemic and strategic intervention.

These results show an objective analysis of how replication may be happening among EC-H2020-SCC Replicate project cities, regardless of being lighthouse cities or fellow cities. Table 3 consequently illustrates how fellow cities are proceeding to formulate their replication plans as a result of a multidirectional, radial, dynamic, iterative, and intentionally more democratic learning process by showing an alternative pathway to pure replication from lighthouse cities to follower cities. The aim of this article is simply showing the case of the EC-H2020-SCC Replicate project further contextualised through a synthetic benchmarking of evidence-based policy documents of the rest of the EC-H2020-SCC lighthouse projects. Needless to say, it goes beyond the scope of this article to assess the feasibility of the replication strategy of the rest of the EC-H2020-SCC lighthouse projects.

\section{Conclusions}

This article constructively contributes to the research on replication among smart cities in the EC-H2020-SCC framework programme by suggesting an alternative strategy to the one implemented by the Replicate project. The article concludes that under the umbrella of the EC-H2020-SCC institutional framework, replication may not be happening as it was intended. Thus, shedding light on this issue, this article presents the main results of the City-to-City Learning Programme undertaken by the EC-H2020-SCC Replicate project for 2019 and proposes the application of five transitions as a conceptual evolution of replication stemming from the social innovation perspective. These five transitions-multidirectional, radial, dynamic, iterative, and more democratic-have, respectively, been suggested as an alternative policy pathway to revert the unidirectional, hierarchical, mechanistic, solutionist, and technocratic rationale behind the given institutional framework. Essentially, these five transitions have played a common core role in the City-to-City Learning Programme by the multiple stakeholders' policy scheme, which resonates with Bryson's [50] (p. 21) following statement: "A wise use of stakeholders can help frame issues that are solvable in ways that are technically feasible and politically acceptable and that advance the common good."

The following five findings provide the evidence to back the five transitions that the City-to-City Learning Programme attempted to experiment with to better achieve an alternative replication pathway by addressing the main objective of this article. Moreover, current COVID-19 momentum is a strong push ahead of using the results of this programme in the formulation of the replication plans of the fellow cities. Actually, as a result of the content of the City-to-City Learning Programme, the fellow cities are actually updating and adapting their plan to the post-COVID-19 landscape by further measuring the positive impact of the selected actions (Table 3). Moreover, given the impact of this pandemic in algorithmic disruption, privacy, and data-related issues, the five transitions seem to have prepared resiliently these fellow cities to adapt (not mechanistically) to the smart city actions. Therefore, the aftermath of COVID-19 and the impact of GDPR have been effectively included in the formulation of the three replication plans. This adaptability and scalability may not be sufficiently flexible if a unidirectional, hierarchical, mechanistic, solutionist, and purely technocratic approach would have already been implemented for assisting fellow cities' replication plans. Fortunately, that has not been the case in the EC-H2020-SCC Replicate project. The following findings are intrinsically 
elaborated from this experimentation in the EC-H2020-SCC Replicate project and, therefore, should not be extrapolated further than the scope of this project. However, these findings may well inspire other replication implementations in smart cities elsewhere.

The first finding of this research is that technocratic unidirectional replication strategies may not be readily adopted by follower-fellow cities primarily because of the lack of adaptability to local contexts and possibly due to the fact that cities require more complex and elaborated interventions to achieve broad social acceptance. During the City-to-City Learning Programme, stakeholders from different Replicate cities engaged in conversations tailored not only to solutions but also to their specific problems. At present, these problems are being filtered through the COVID-19 aftermath by having a constructive conversation to achieve further resilient actions. This situation was particularly noteworthy for the cases of Essen and Nilüfer, where, despite their clear differences, they actively exchanged their ideas about energy regulations and organisational forms of cooperatives and, even, came up with solutions different from those already experimented in other cities, regardless of whether they were lighthouse or follower-fellow cities. The interest in energy co-operatives was shared by two fellow cities altogether, a situation that might not have been possible if a unidirectional logic had been implemented, as the mainstream EC-H2020-SCC policy approach indicated.

Consequently, the second finding is that the policy design of the EC-H2020-SCC framework programme advocating a hierarchical model from the lighthouse to the follower-fellow cities may be the source of the lack of adoption of strategies for replication. Put differently, the given selection of smart city initiatives in the lighthouse cities, subject to be replicated by the follower-fellow, may well be misaligned. This situation includes the selection of the sector, specific actions deployed, and, more importantly, stakeholders who are directly or indirectly affected [101]. The given hierarchical model can "exclude the perspectives and interests of citizens" and particular groups of stakeholders [102] (p. 1). For instance, the replication plans of the three fellow cities have produced highly relevant content regarding data protection and governance in line with the GDPR, even advancing several aspects not even assessed in the smart city actions of the lighthouse projects. To sum up, the EC-H2020-SCC framework programme was designed for interventions that last five years. As we can effectively observe in the course of the current events, neither digital rights to protect citizens as advocated by the GDPR were in the smart city policy agenda, nor once COVID-19 occurred, requesting quick and radial updates to achieve a resilient and smart response to the pandemic in reducing vulnerabilities by which citizens are increasingly exposed when using public transport. Social innovation shows that resilient measures are reliant on social capital, trust, and the way stakeholders may cope with uncertainties and emergencies, rather than on hierarchical interventions as the EC-H2020-SCC framework programme initially anticipated. Essen, Lausanne, and Nilüfer are adapting, updating, and innovating, at present, smart city actions being discussed in the City-to-City Learning Programme. The programme allowed the building of a social infrastructure to further prepare the network to keep on examining interventions.

How, then, can replication be implemented among smart cities? This article, by contrasting several conclusions and the main hypothesis extracted by Vandervyvere [36] through intense and continuous fieldwork action research from 2016, and more particularly for 2019 with 150 stakeholders participating actively in the City-to-City Learning Programme, suggests (as a third finding) a dynamic vision of replication by which stakeholders adopt and adapt their particular interventions to their own circumstances. During the webinar sessions, stakeholders from fellow cities further asked specific questions about adapting, tailoring, prototyping, or scaling up certain tested interventions. The three fellow cities are, at present, adapting their actions by even directly contacting stakeholders from the lighthouse and other fellow cities. The identification of a different typology of stakeholders and, particularly, specific stakeholders in each city now allows fellow cities to follow a dynamic approach.

Judging from the potential replication plans of fellow cities (as shown in Table 3), the fourth finding is related to the iterative nature of the decision-making process in each fellow city rather than copy-pasting solutions $[14,40]$. After a comprehensive benchmarking that generically and synthetically analysed the replication strategies of the 17 lighthouse projects (as shown in Table 1), the City-to-City 
Learning Programme in the Replicate project has anticipated debates around the GDPR, algorithmic disruption, data privacy, and ownership that generate increasingly more timely techno-political issues than sectoral technical interventions have so far identified [72,103-105], which makes the function of replication from the ethical and social standpoints even more complicated. Without going into detail about each smart city action being adapted now due to the COVID-19 aftermath, the Replicate project is now experiencing a prominent level of discussion where actions implemented in Essen (SS.1., SS.3., F.1., F.2., L.1., B.1., B.2., B.3., and N.2.), in Lausanne (SS.1., SS.3., E.3., F.2., B.1., and B.3.), and in Nilüfer (E.1., B.1., B.2., and B.3.) are being reshaped through an iterative process beyond the solutionist logic. Actually, two new sections have been included in the replication plans of the three cities: (i) the first one related to data governance issues and how to protect citizens' digital vulnerabilities and (ii) a second one related to the specific pandemic measurements in the selected actions of their replication plans. To sum up, broadly, in the three fellow cities, mobility actions are being re-considered in light of social distancing; walking and biking have been prioritized, and teleworking has become the norm, fundamentally strengthening its technical infrastructure to ease the digital transition and related transformations. Nonetheless, citizens' engagement and grassroots innovation are probably suffering the most: In the three fellow cities, participative processes are stopped and direct democracy (particularly relevant in Lausanne and Nilüfer, despite clear differences in procedures) will be sharply curtailed in the aftermath of the pandemic. Thus, nuanced and locally-rooted measurements are showing the importance of having avoided the solutionist rationale in favor of further iterative settings.

The final finding concerns the narrative that underpins the smart city. Habermas argues that smartness in cities cannot be more technocratic than democratic [106]. Above all, smartness postulates that problems and their solutions are presented as being interlinked only within a technical nature; and yet, democracy in cities does not merely stem from techniques. The current pandemic crisis and democracy are pervasively related to data governance issues, exposing citizens' vulnerability in a potential surveillance state. Democracy has been in recession for over a decade, and many fear that COVID-19 has already accelerated this trend. As such, technocratic replicability may be found in the core of the black box algorithmic era. Smart cities purely replicating models may thus end up clearly fostering the lack of democratic accountability and thus, inevitably neutralizing even the watchdog role of local stakeholders. In this direction, this article attempted to focus on the learning process among cities and, therefore, their stakeholders, by overlooking the neutral vision of technology, led by policymakers, to disregard equality and diversity issues, although the smart city-and its products and services-is not similarly accessible to every stakeholder. In line with the argument by Nesti and Graziano by which the technical nature of urban problems is required to be reframed in (techno-)political terms, this article showed and opened up directions for future replication research from the social innovation perspective [6]: There is significant room for manoeuvre for local stakeholders in their ability to pick and choose, adapt, and prototype between innumerable intervention models and networks. Their capacity to produce insightful narratives while learning from each other may also mean that cities and their stakeholders can seize the current pathway and fashion new alternatives for the future [82,107-109].

Funding: This research was funded by the European Commission (EC) under the grant number H2020-SCC-691735-REPLICATE and ESRC under the Urban Transformations programme grant number ES/M010996/1.

Acknowledgments: Particularly thank to Euken Sesé and Elisabeth Jorge from Fomento San Sebastian for their leadership in H2020-SCC-691735 Replicate project. Furthermore, the author is grateful for the support provided by the University of Oxford at COMPAS, particularly by M. Keith.

Conflicts of Interest: The author declares no conflict of interest.

Data Availability: The data that support the findings of this article are openly available in the City-to-City Learning Programme at www.replicate-project.eu/city2citylearning. 


\section{References}

1. Borsboom-van Beurden, J.; Kallaos, J.; Gindroz, B.; Costa, S.; Riegler, J. Smart City Guidance Package: A Roadmap for Integrated Planning and Implementation of Smart City Projects; EIP-SCC: Brussels, Belgium, 2019.

2. Coletta, C.; Evans, L.; Heaphy, L.; Kitchin, R. Creating Smart Cities (Series Regions and Cities); Routledge: Oxon, UK, 2018.

3. EIP-SCC. Towards a Joint Investment Programme for European Smart Cities: A Consultation Paper to Stimulate Action; EC: Brussels, Belgium, 2016.

4. Johnson, P.A.; Robinson, P.J.; Philpot, S. Type, tweet, tap, and pass: How smart city technology is creating a transactional citizen. Gov. Inf. Q. 2019, 37, 101414. [CrossRef]

5. Kitchin, R.; Coletta, C.; Evans, L.; Heaphy, L.; Mac Donncha, D. Smart Cities, Urban Technocrats, Epistemic Communities and Advocacy Coalitions: The Programmable City Working Paper 26; National University of Ireland Maynooth: County Kildare, Ireland, 2017.

6. Nesti, G.; Graziano, P.R. The Democratic Anchorage of Governance Networks in Smart Cities: An Empirical Assessment. Public Manag. Rev. 2019, 22, 1-20. [CrossRef]

7. Trencher, G. Towards the Smart City 2.0: Empirical evidence of using smartness as a tool for tackling social challenges. Technol. Forecast. Soc. Chang. 2018, 142, 117-128. [CrossRef]

8. Calzada, I. Technological sovereignty: Protecting Citizens' digital rights in the AI-driven and post-GDPR algorithmic and city-regional european realm. Reg. eZine 2019, 4, 1-17. [CrossRef]

9. Janssen, M.; Kuk, G. The challenges and limits of big data algorithms in technocratic governance. Gov. Inf. Q. 2016, 33, 371-377. [CrossRef]

10. Komninos, N.; Kakderi, C. Smart Cities in the Post-Algorithmic Era: Integrating Technologies, Platforms and Governance; Edward Elgar: Chentelham, UK, 2019.

11. Calzada, I. Smart City Citizenship; Elsevier Science Publishing Co. Inc.: Cambridge, MA, USA, 2021; ISBN 9780128153000.

12. Zuboff, S. The Age of Surveillance Capitalism: The Fight for a Human Future at the New Frontier of Power; Profile: London, UK, 2019.

13. SCIS. Available online: https://smartcities-infosystem.eu/scc-lighthouse-projects (accessed on 1 June 2020).

14. EC (European Commission). Creating the Links for Scaling Smart Cities Solutions; H2020: Eindhoven, The Netherlands, 2016.

15. EC. EU Research E Innovation for and with Cities; EC: Brussels, Belgium, 2017.

16. EC. The Making of a Smart City: Policy Recommendations; EC: Brussels, Belgium, 2017.

17. EC. The Making of a Smart City: Replication and Scale-Up of Innovation in Europe; EC: Brussels, Belgium, 2017.

18. EC. The Making of a Smart City: Best Practices Across Europe; EC: Brussels, Belgium, 2017.

19. Aurigi, A.; Odendaal, N. From 'Smart In The Box' to 'Smart In The City': Rethinking the socially sustainable smart city in context. J. Urban Technol. 2020,1-16. [CrossRef]

20. Cardullo, P.; Kitchin, R. Smart urbanism and smart citizenship: The neoliberal logic of 'Citizen-Focused' smart cities in Europe. Environ. Plan. C Politics Space 2019, 37, 813-830. [CrossRef]

21. Caragliu, A.; Del Bo, C.; Nijkamp, P. Smart cities in Europe. J. Urban Technol. 2011, 18, 65-82. [CrossRef]

22. Bartels, K. Transforming the relational dynamics of urban governance: How social innovation research can create a trajectory for learning and change. Urban Stud. 2020, 1-17. [CrossRef]

23. Heinelt, H.; Terizakis, G. Innovative cities: How to explain differences between cities? An answer based on an interpretive approach. Urban Res. Pract. 2020, 1-15. [CrossRef]

24. Potjer, S.; Hajer, M. Learning with Cities, Learning for Cities: The Golden Opportunity of the Urban Agenda for the EU; Utrecht University: Utrecht, The Netherlands, 2017.

25. Barns, S. Platform Urbanism: Negotiating Platform Ecosystems in Connected Cities; Springer: Singapore, 2020. [CrossRef]

26. Dyer-Witheford, N. Left populism and platform capitalism. Triple C J. Glob. Sustain. Inf. Soc. 2020, 18, 116-131. [CrossRef]

27. Graham, M. Regulate, replicate, and resist-The conjunctural geographies of platform urbanism. Urban Geogr. 2020, 41, 453-457. [CrossRef]

28. Sadowski, J. Cyberspace and cityspaces: On the emergence of platform urbanism. Urban Geogr. 2020, 41, 448-452. [CrossRef] 
29. Graham, M.; Kitchin, R.; Mattern, S.; Shaw, J. How to Run a City Like Amazon, and Other Fables; MeatSpacePress: London, UK, 2019.

30. Woodcock, J.; Graham, M. The Gig Economy: A Critical Introduction; Polity: London, UK, 2019.

31. Grimmelikhuijsen, S.; Porumbescu, G.A. Reconsidering the expectancy disconfirmation model. Three experimental replications. Public Manag. Rev. 2017, 19, 1272-1292. [CrossRef]

32. Jilke, S.; Petrovsky, N.; Meuleman, B.; James, O. Measurement equivalence in replications of experiments: When and why it matters and guidance on how to determine equivalence. Public Manag. Rev. 2017, 19, 1293-1310. [CrossRef]

33. Kitchin, R. Urban science: A short primer. In The Programmable City Working Paper 23; National University of Ireland Maynooth: County Kildare, Ireland, 2017.

34. Riegler, J. Scaling up E Replication of Smart City and Community Plans; JPI Urban Europe: Brussels, Belgium, 2017.

35. Walker, R.M.; James, O.; Brewer, G.A. Replication, experiments and knowledge in public management research. Public Manag. Rev. 2017, 19, 1221-1234. [CrossRef]

36. Vandervyvere, H. Recommendations on EU REI and Regulatory Policies: Why May Replication (Not) Be Happening? EU SCIS: Brussels, Belgium, 2017.

37. Datta, A. The 'Urban' Is not 'Science' [Tweet]. 2018. Available online: https:/twitter.com/AyonaDatta/status/ 1014186757187874817 (accessed on 1 June 2020).

38. Forester, J.; Kuitenbrouwer, M.; Laws, D. Enacting reflective and deliberative practices in action research. Policy Stud. 2019, 40, 456-475. [CrossRef]

39. Higdem, U. The co-creation of regional futures: Facilitating action research in regional foresight. Futures 2014, 57, 41-50. [CrossRef]

40. Morozov, E. To Save Everything, Click Here: The Folly of Technological Solutionism; PublicAffairs: New York, NY, USA, 2013.

41. Terstriep, J.; Rehfeld, D.; Kleverbeck, M. Favourable social innovation ecosystem(s)?-An explorative approach. Eur. Plan. Stud. 2020, 28, 881-905. [CrossRef]

42. Mihci, H. Is measuring social innovation a mission impossible? Innov. Eur. J. Soc. Sci. Res. 2020, 33, 337-367. [CrossRef]

43. Moulaert, F.; MacCallum, D. Advanced Introduction to Social Innovation; Edward Elgar: Cheltenham, UK, 2019.

44. Pel, B.; Wittmayer, J.; Dorland, J.; Jørgensen, M.S. Unpacking the social innovation ecosystem: An empirically grounded typology of empowering network constellations. Innov. Eur. J. Soc. Sci. Res. 2020, 33, 311-336. [CrossRef]

45. ReplicateEU. City-to-City-Learning Programme. Available online: www.replicate-project.eu/city2citylearning (accessed on 1 June 2020).

46. SCIS. REPLICATE \#City2CityLearning. Available online: https://smartcities-infosystem.eu/newsroom/news/ replicate-city2citylearning (accessed on 1 June 2020).

47. SUI (Smart Urban Intermediaries). Smart Cities, Social Innovation and Smart Urban Development; University of Edinburgh: Edinburgh, UK, 2018.

48. Poppen, F.; Decker, R. The intermediary as an institutional entrepreneur: Institutional change and stability in triple-helix cooperation. Triple Helix 2018, 5, 1-22. [CrossRef]

49. Calzada, I.; Cowie, P. Beyond smart and data-driven city-regions? Rethinking stakeholder-helixes strategies. Reg. Mag. 2017, 308, 25-28. [CrossRef]

50. Bryson, J.M. What to do when stakeholders matter. Public Manag. Rev. 2004, 6, 21-53. [CrossRef]

51. Schubert, C. Social innovation. A new instrument of social change? In Innovation Society Today. Perspectives, Fields, and Cases; Windeler, A., Rammert, W., Hutter, M., Knoblauch, H., Eds.; Springer: Wiesbaden, Germany, 2018; pp. 371-391.

52. Voorberg, W.H.; Bekkers, V.J.J.M.; Tummers, L.G. A systematic review of co-creation and co-production: Embarking on the social innovation journey. Public Manag. Rev. 2015, 17, 1333-1357. [CrossRef]

53. Atelier. Available online: http://www.smartcity-atelier.eu/ (accessed on 1 June 2020).

54. City Exchange. Available online: https://cityxchange.eu/demo-projects/ (accessed on 1 June 2020).

55. MakingCity. Available online: http://makingcity.eu/city-profiles/ (accessed on 1 June 2020).

56. Matchup. Available online: https://www.matchup-project.eu/news/when-a-follower-takes-the-floor (accessed on 1 June 2020).

57. Pocityf. Available online: https://pocityf.eu/ (accessed on 1 June 2020). 
58. Ruggedised. Available online: https://ruggedised.eu/project/about/ (accessed on 1 June 2020).

59. Sparcs. Available online: https://www.sparcs.info/objectives (accessed on 1 June 2020).

60. Stardust. Available online: http://stardustproject.eu/all-cities/ (accessed on 1 June 2020).

61. Triangulum. Available online: https://www.triangulum-project.eu/?page_id=3576 (accessed on 1 June 2020).

62. Growsmarter. Road to Replication-Guiding Cities on Smart Urban Development: Process and Lessons Learned in Growsmarter. Available online: www.grow-smarter.eu/home (accessed on 1 June 2020).

63. Smarter Together. Available online: https://www.smarter-together.eu/file-download/download/public/1177 (accessed on 1 June 2020).

64. IRIS. Transition Strategy, Commissioning Plan for the Demonstration and Replication. Available online: https://irissmartcities.eu/system/files/private/irissmartcities/d1.7_transition_strategy_commissioning_ plan_for_the_demonstration_replication_v1.2.pdf (accessed on 1 June 2020).

65. MySmartLife. D.6.14 mySMARTLife Cities Network Replication Activities Planning. Available online: https://www.mysmartlife.eu/fileadmin/user_upload/Deliverables/D6.14_mySMARTLife_Cities_Network_ replication_activities_planning.pdf (accessed on 1 June 2020).

66. SmartenCity. Available online: https://smartencity.eu/news/detail/?rx_call=124 (accessed on 1 June 2020).

67. Remourban. D.5.2. Model for Replication Potential. Available online: www.remourban.eu (accessed on 1 June 2020).

68. Sharing Cities. Available online: http://nws.eurocities.eu/MediaShell/media/Onereplicationstrategy.pdf (accessed on 1 June 2020).

69. SCIS/Replicate/City2CityLearning. Available online: http://www.smartcities-infosystem.eu/newsroom/news/ replicate-city2citylearning (accessed on 16 January 2020).

70. Gillespie, T. The Politics of "Platforms". New Media Soc. 2010, 12, 347-364. [CrossRef]

71. Chisnall, M. Digital slavery, time for abolition? Policy Stud. 2020, 41, 488-506. [CrossRef]

72. Calzada, I. Data spaces and democracy. RSA J. 2019, 2, 40-43. [CrossRef]

73. Timeus, K.; Vinaixa, J.; Pardo-Bosch, F. Creating business models for smart cities: A practical framework. Public Manag. Rev. 2020, 22, 726-745. [CrossRef]

74. García-Fuentes, M.A.; Quijano, A.; de Torre, C.; García, R.; Compere, P.; Degard, C.; Tomé, I. European cities characterization as basis towards the replication of a smart and sustainable urban regeneration model. Energy Procedia 2017, 111, 836-845. [CrossRef]

75. von Radecki, A. Triangulum: Demonstrate-Disseminate-Replicate. D.6.2. Smart City Replication Framework. 2018. Available online: https://www.triangulum-project.eu/wp-content/uploads/2018/10/2018-01_D6.2Smart-City-Framework.pdf (accessed on 1 July 2020).

76. Bable. Available online: www.bable-smartcities.eu (accessed on 1 June 2020).

77. Engelbrecht, H.-J. The (Social) innovation—Subjective well-being nexus: Subjective well-being impacts as an additional assessment metric of technological and social innovations. Innov. Eur. J. Soc. Sci. Res. 2018, 31, 317-332. [CrossRef]

78. Grimm, R.; Fox, C.; Baines, S.; Albertson, K. Social innovation, an answer to contemporary societal challenges? Locating the concept in theory and practice. Innov. Eur. J. Soc. Sci. Res. 2013, 26, 436-455. [CrossRef]

79. Calzada, I.; Cobo, C. Unplugging: Deconstructing the smart city. J. Urban Technol. 2015, 22, 23-43. [CrossRef]

80. Calzada, I. Deciphering smart city citizenship: The techno-politics of data and urban co-operative platforms. Rev. Int. Estud. Vascos RIEV 2018, 63, 42-81. [CrossRef]

81. Calzada, I.; Keith, M. Bridging European Urban Transformations Workshop Series 2016-2018. @Utconnect Digest; University of Oxford/ESRC: Oxford, UK, 2018.

82. Wathne, M.W.; Haarstad, H. The smart city as mobile policy: Insights on contemporary urbanism. Geoforum 2020, 108, 130-138. [CrossRef]

83. Amin, A.; Thrift, N. Seeing Like a City; Polity: Cambridge, UK, 2017.

84. San Sebastian. Available online: https://replicate-project.eu/1st-session-excellence-of-service-provisionbased-on-data-monitoring-and-smart-management (accessed on 1 June 2020).

85. Leycolan. Available online: www.leycolan.com (accessed on 1 June 2020).

86. Eurohelp. Available online: www.eurohelp.es (accessed on 1 June 2020).

87. Ikusi. Available online: www.ikusi.com (accessed on 1 June 2020).

88. Essen 51. Available online: www.thelen-gruppe.com/essen51 (accessed on 1 June 2020).

89. Camp-Essen. Available online: www.camp-essen.de (accessed on 1 June 2020). 
90. Impact Hub Ruhr. Available online: www.ruhr.impacthub.net (accessed on 1 June 2020).

91. Essen. Available online: https://replicate-project.eu/2nd-session-the-new-smelters-of-the-coal-heartland/ (accessed on 1 June 2020).

92. Florence. Available online: https://replicate-project.eu/3rd-session-go-fast-go-green-get-connceted-thatssmart/ (accessed on 1 June 2020).

93. eDistribuzione. Available online: www.e-distribuzione.it (accessed on 1 June 2020).

94. Lausanne. Available online: https://replicate-project.eu/4th-session-roadmap-for-the-realization-of-aneco-district-including-development-of-medium-depth-geothermal-energy-in-urban-areas/ (accessed on 1 June 2020).

95. Bristol. Available online: https://replicate-project.eu/5th-session-collaborating-with-communities-creatingthe-future-cities-we-need/ (accessed on 1 June 2020).

96. Calzada, I. The techno-politics of data and smart devolution in city-regions: Comparing glasgow, bristol, barcelona, and bilbao. Systems 2017, 5, 18. [CrossRef]

97. Allen, B.; Tamindael, L.E.; Bickerton, S.H.; Cho, W. Does citizen coproduction lead to better urban services in smart cities projects? An empirical study on e-participation in a mobile big data platform. Gov. Inf. Q. 2020, 37, 101412. [CrossRef]

98. KWMC. Available online: https://kwmc.org.uk/ (accessed on 1 June 2020).

99. Nilüfer. Available online: https://replicate-project.eu/6th-session-socio-economic-development-from-below/ (accessed on 1 June 2020).

100. Nilüfer Kent Konseyi. Available online: http://www.niluferkentkonseyi.org (accessed on 1 June 2020).

101. Eubanks, V. Automating Inequality: How High-Tech Tools Profile, Police, and Punish the Poor; St. Martin's Press: New York, NY, USA, 2017.

102. Engelbert, J.; van Zoonen, L.; Hirzalla, F. Excluding citizens from the European smart city: The discourse practices of pursuing and granting smartness. Technol. Forecast. Soc. Chang. 2018, 142, 347-353. [CrossRef]

103. Bigo, D.; Isin, E.; Ruppert, E. Data Politics; Routledge: London, UK, 2019.

104. Madsen, A.K. Data in the smart city: How incongruent frames challenge the transition from ideal to practice. Big Data Soc. 2018, 5, 1-13. [CrossRef]

105. van Dijck, J. Datafication, dataism and dataveillance: Big data between scientific paradigm and ideology. Surveill. Soc. 2014, 12, 197-208. [CrossRef]

106. Habermas, J. The Lure of Technocracy; Polity Press: London, UK, 2015.

107. Späth, P.; Knieling, J. How EU-funded smart city experiments influence modes of planning for mobility: Observations from Hamburg. Urban Transform. 2020, 2, 1-17. [CrossRef]

108. Noori, N.; de Jong, M.; Hoppe, T. Towards an integrated framework to measure smart city readiness: The case of iranian cities. Smart Cities 2020, 3, 676-704. [CrossRef]

109. Allam, Z.; Newman, P. Redefining the smart city: Culture, metabolism and governance. Smart Cities 2018, 1, 4-25. [CrossRef]

(C) 2020 by the author. Licensee MDPI, Basel, Switzerland. This article is an open access article distributed under the terms and conditions of the Creative Commons Attribution (CC BY) license (http://creativecommons.org/licenses/by/4.0/). 